\title{
Collaboration and Visibility: Changing Relations Between Socially Engaged Art, Anthropology and Urban Sphere in Turkey ${ }^{1}$
}

\author{
Ayşe Güngör \\ aysegungor@gmx.de \\ Technische Universität Berlin, Art History Department
}

To cite this paper: GÜNGÖR, Ayşe - Collaboration and Visibility: Changing Relations Between Socially Engaged Art, Anthropology and Urban Sphere in Turkey. Estudo Prévio 15. Lisboa: CEACT/UAL - Centro de Estudos de Arquitetura, Cidade e Território da Universidade Autónoma de Lisboa, 2019. ISSN: 2182-4339 [Available at: www.estudoprevio.net]. DOI: https://doi.org/10.26619/2182-4339/15.3

Received on 19 February 2019 and accepted for publication on 30 June 2019.

Creative Commons, licence CC BY-4.0: https://creativecommons.org/licenses/by/4.0/

\begin{abstract}
After the 1990s, the number of art fairs, events and biennials in Turkey has not only increased but also the involvement of art world institutions in the art scene has transformed the practices of contemporary artists. This transformation resulted in a growing interest in socially engaged practices that are characterized by engagement and dialogue of the artists with the communities. I investigate the historical and social background for the proliferation of sociopolitical interest in art through the major sociopolitical changes in Turkey. I aim to illustrate the role of the artists working with communities in the urban sphere, with their potential to raise awareness on the community's struggle, predominantly by making them 'visible' with the artistic process. My paper focuses on this interaction between artists and communities in the urban context from an anthropological perspective in order to address the role and potential of art practices while creating events with participatory processes. In conclusion, this paper sheds new light on the potentialities of anthropological analysis of socially engaged art by examining this interaction using some examples in Turkey.
\end{abstract}

Keywords: Art and Social Change, Relational Art, Art and Anthropology, Socially Engaged Art, Contemporary Art in Turkey 


\section{The Emergence of Socially Engaged Art in Turkey}

The contemporary art scene in Turkey today is constantly changing and, its actors transform and adapt to these changes. 1990s contemporary art was marked by a significant change, specifically in terms of exhibition methods as a result of leaving state's modernist view on art and culture behind. However, contrasting with the state's modernist agenda, there was a lack of state support to art and culture at this time, alongside the crisis of cultural foundation and inaccurate cultural politics.

On the other hand, the neoliberal reforms in Turkey in the 1980s were directly related to state enforcement. With the growth of neoliberalism, the private sector gained significant financial power, resulting in a shift from public to private cultural activities, as the state encouraged private investment in the cultural sector. According to Yardimci, the impact of big investment through sponsorship or board of trustees on the prominent museums and festivals (Koc, Sabanci, Eczacibasi), publishers (Yapi Kredi), art galleries (Akbank, Garanti), and even universities (Koc, Sabanci, Bilgi), shows how economic and cultural capital influenced each other.2 Therefore, with the investments of leading companies and financial institutions, the cultural atmosphere in Turkey changed rapidly and continues to change.

Considering these developments, it is possible to realize that contemporary art in Turkey was not dependant on state support, but was becoming more independent. These investments from the private sector emerged with the idea of democratizing art. Since funding sources were now philanthropic organizations, they aimed to provide a framework for alternative practices in art, which would challenge the artistic practices of state's art education and its modernist principles.

The increasing number of art galleries in Turkey between 1990 and 2000 clearly showed the increasing dominance of new galleries in the field of contemporary art. 3 Moreover, international curators began to take a leading role in various exhibitions and gained a voice in Turkish contemporary art. Moreover, artistic residencies, artists going abroad, international art organizations in Turkey and, especially, the general interest in art by artists in Istanbul, generated a new and lively art scene in Turkey.

All these changes stemming from the institutionalization in art led to artists tending to be more involved in the issues related to identity politics. The role of Turkey's EUintegration process cannot be denied in this context, as this process intended to strengthen cultural relations. During this process, the attempts were mostly aimed at building connections between the big cities (most often Istanbul) and the cities in the Eastern side of Turkey.4 In this regard, the cultural policies tried to present the social diversity in Turkey through the agency of art, in tune with the socio-political strategies of European cultural policy.

The involvement of artists addressing cultural identity made artistic practices for social change, namely, helping marginalized communities through art, become common practice. As Kwon states in her influential article with a focus on "site-specific art", "the critique of the cultural confinement of art (and artists) via its institutions was once the 'great issue,' a dominant drive of site-oriented practice today is the pursuit of a more intense engagement with the outside world and everyday life" 5 , that is to say, art 
incorporated into the field of social issues with a focus on the everyday life of specific communities.

Bearing this in mind, artists who reflect on the socio-political realities of their times could only have arisen with the dynamics that non-governmental institutions brought to contemporary art. The involvement of private cultural institutions arguably contributed to the freedom of expression in contemporary art, leading to alternative practices, as socially engaged art emerged in Turkey. In this respect, it is also important to emphasize the transformative aspect of Istanbul Biennial from its beginning, considering the construction of new relations between social life in the city and the practices of the artists. Furthermore, with the involvement of private sector in art, the artistic interest in socio-political issues in Turkey became more widespread. The institutionalization process of contemporary art in Turkey had a crucial impact on this transformation, since institutions also supported socially engaged practices of the artists.

\section{Artists' Social Agenda in an Urban Context}

The development of cultural policies in the 1990s, particularly with the impact of Turkey's EU-accession process, forms an essential basis for understanding the influence of globalization and the reflection of identity politics on art. In the years following 1990s, biennials adapted to the global art world, and the Turkish art scene gained an international interest. With the Istanbul Biennial and cultural tourism as its extension, an increasing number of artists began to engage in social practices, and become more engaged with social issues by using ethnographic research methodology with a focus on participation and collaboration.

This transformation was a part of the social turn in art, which Claire Bishop historicizes in three different moments. The first is the historic avant-garde in Europe around 1917, the second, the so called neo-avant-garde (until 1968), and the third, the resurgence of participatory art in the 1990s, which leads her to claim that the fall of communism in 1989 is the third point of transformation. According to Bishop, "each phase was accompanied by a utopian rethinking of art's relationship to the social and of its political potential." 6 This perspective coincides with the transformation of art practices in Turkey after the 1990s, in terms of the emergence of social and political references within contemporary art. Thus, the potential of contemporary art in finding new ways of engaging with current social and political issues came into prominence.

Artists have endeavoured to attain social change through collaboration with communities. While researching the proliferation of socially engaged art in Turkey, we realized that the impact of globalization and growing support of the private sector to art played an important role. This support created a basis for artistic freedom, providing artists with the means to leave the gallery context and merge life with art.

With the involvement of concepts such as "relational aesthetics" which French art critic Nicolas Bourriaud highlighted in the early 1990s, artists tended to be more involved in collective practices by collaborating with communities, leading to the increase in socially-engaged art practices. In this respect, Baykal illustrates: 
"In the 1990s, the centers on the international art map began to show increasing interest in the periphery, along with the globalization and the European Union's changing cultural policies. The social integration strategies in European countries that experienced immigration and explorations of the possibilities of coexistence, despite differences caused the concept of the "other" to come noticeably to the fore." (BAYKAL, 2010: 42)

As a consequence of the emergence of these cultural policies, an awareness of different identities and the concept of "other" have been disseminated. In this respect, it is important to underline the effects of Turkey's EU accession process, as this process has accentuated the "cultural difference" context. The context of European integration and urban transformations produced a dynamic framework for cultural policies. Together with these cultural policies, many artists focused on migration issues, as well as on the effects of issues of their time. The massive wave of the migration from the Eastern region of Turkey to the big cities in the 1990s impacted everyday life, especially the social and urban structure of Istanbul, and contributed to the growing interest in identity issues. Consequently, many artists have undertaken the role of representing the social problems in their works, which inevitably relate to their experiences in big cities.

The growing artistic interest in current social issues in the urban context was also related with the changes in the political and demographic situation of the country, notably, the migration from the rural areas to the big cities. The migration had extensive social and political consequences in life in cities while making big cities the main economic, historical, and cultural centre of the country. This process reinforced the position and potential of Istanbul as a major cultural centre. Artists also adapted to these changes by conceptualizing urbanization and its consequences in their works.

The focus of artists on urban transformation in Istanbul has mostly emerged in districts where the population is economically disadvantaged and there is ethnical diversity. This has taken the form of observational practices by artists intending to defend their rights and show solidarity. For instance, Pelin Tan describes a case related to this, that of the controversial demolition of Sulukule, a Romani neighborhood in Istanbul, and the artists' solidarity with the inhabitants of this area. Tan states that the artists closely analysed the urban transformation in several districts and that "their artistic interventions take the form of documenting the process of eviction from the neighborhoods or of their collaboration with urban collectives." 7 Collaboration with residents has been chosen as an artistic strategy meant to raise awareness to their ongoing resistance. Hence, the case of Sulukule resistance illustrates the potential of art for political and social change, with a reference to collaboration and visibility in artistic practices.

Neoliberal urbanism and the migration from the East to the big cities led to the existence of specific neighborhoods where migrants from different ethnic backgrounds lived and to changes in city planning. Many artists began directing their interests to social changes. The most prominent change was included in the agenda for "urban transformation" - urban regeneration projects in inner city areas as part of neoliberal 
urban policies. This change is then linked to the struggles of those defending the rights of the inhabitants of those city areas, as mentioned in the case of Sulukule. Urban transformation is a significant element of this social change, and has become a topic in artists' social agendas and their focus on inequalities in the living conditions of different urban populations.

\section{Artistic Practices Between Art and Anthropology}

When looking at the contemporary art scene from a social scientific perspective, it is possible to observe the dynamics of transformation that have taken place with the involvement of private institutions in the culture industry. Politically motivated art becomes visible, displaying the social life of the communities and the issue of representation. Kortun and Kosova describe this transformation when they discuss the development of contemporary art in Turkey. According to them, the cultural environment that focused on idealized proletarian figures in the 1970s tended to focus on the new migrants in the cities in the 1980s, and to different norms or segments of those living in the peripheral areas of the city in the 1990s. The best example of this transition would be that of Gülsün Karamustafa. While working as an art director in the film sector, her piece Merdiven (2001) showed playful Romanian children who came to Istanbul for three months in order to earn money in the streets. Kortun and Kosova refer a similar work, an Esra Ersen's piece, This is the Disney World (2000), documenting glue-sniffing street kids in Taksim, Istanbul.8

Following this trend, a considerable numbers of artists from Turkey also depict social issues in their work. As mentioned above, the increase in private sector institutionalization and globalization had a significant impact on the transformations of concepts in the contemporary art in Turkey. As a result of these changes, adopting ethnographic methods for the study of culture with participatory and collaborative methods became more prevalent.

As the boundaries between anthropology and artistic practices disappear, these works contribute with new approaches to representation. When Marcus introduced the concept "aesthetics of fieldwork" in his essay9 as experimentation for the practice of anthropology, his attempt was signalling new paths, away from classical anthropology practice. Anthropologist Tim Ingold criticized ethnography, as it excludes the new methods of doing anthropology, and he claimed that by leaving ethnography, interdisciplinary collaborations with different fields would be possible, such as combining art practice and anthropology. 10 Today, anthropological methods are intertwined with artistic practices to generate productive engagements and possibilities between the two fields. With the global emergence of socially engaged practices in art, the significance of anthropology became evident, especially through the concepts of "collaboration" and "participation" that were already a concern in anthropology. As a result of this, anthropology became a substantial source of reference and also an inspiration for these socially engaged art practices while artistic practices became more involved in the anthropological field. 
In this context, the role of anthropology in these artistic practices must be discussed by rethinking the consequences of social turn in contemporary art. I argue that conducting research with a community to observe and document their lives became a frequent topic for Turkish art until the 1990s. By employing a methodology that includes different methods to answer research questions, artists aim to reach a better understanding of the dynamics of the community in the urban sphere.

For instance, in the Becoming a Place (2001) exhibition, Oda Projesi's site-specific work exemplified how artists employed Istanbul's urban transformation. For this 2001 project, Oda Projesi11 used the houses in the Gültepe neighborhood as an exhibition space. Gültepe was initially a shantytown built by immigrants coming from the Eastern and Southern regions of Turkey. During the project, Oda Projesi organized interactive exhibitions with the neighbors and the children in the Oda Projesi space in Gültepe. Once a month, in the Project4L museum, students participated in artist-led workshops, so that they could closely engage with the exhibitions through discussions on topics, techniques and contemporary art.12

Since then, Oda Projesi has been focusing on urban spaces in terms of their different purposes, based upon social relations and their potentials; they aim to produce collaborative events by organizing meals, discussions, workshops, exhibitions, and screenings in various neighborhoods. Bishop also states the importance of Oda Projesi's works in terms of "opening up the space for non-object-based practice in Turkey", and she adds that it is " a country whose art academies and art market are still largely oriented toward painting and sculpture."13 Bishop's statement emphasizes the changing patterns in Turkish art through establishing links with the socially engaged art.

For instance, Kutlug Ataman's Küba (2004) consists of videos that feature interviews with forty residents of a shantytown neighborhood on the outskirts of Istanbul. The residents call this area Küba, an unofficial name for this area. This area is the home to "impoverished Turks and Kurds, religious fundamentalists, political dissidents and other disparate individuals who are bound to solidarity by their outsider status." 14 For this video, Ataman interviewed forty residents of this area, who told their own stories and experiences about living on the outskirts of Istanbul. Ataman uses participantobservation method with an emphasis on observation to delve deeper into a stereotyped image of this community - in this case, "Küba", a neighborhood defined by the Kurdishness of the inhabitants.

To determine the stereotype content or decode the cultural stereotypes in both of these cases, Ataman presents the interviewees expressing their unique individuality. $\mathrm{He}$ creates this ethnographic dialogue by asking questions about their lives during the video interviews to reach an understanding of their living conditions and problems. However, these sorts of art practices conducted with closed communities, such as in the case of "Küba", require more responsibility because of the risk of revealing identities. As Çakırlar mentions in his article, "recalling also that the Kübans did not allow the artist to exhibit this work in Turkey, I would argue that there is a considerable risk and challenge for an artist to attempt to portray a community - that excessively invests in its own regional belonging and refuses to be represented in Turkey - to a 
global audience." 15 Those dissatisfied with the collaboration come into focus in the case of collaboration with close communities.

As another instance, Esra Ersen, engages with communities in the city at particular sites and cooperates closely with the specific communities in order to build a trusting relationship with them. Passengers (2009), produced as a two-channel video for exhibition in Tanas Gallery, Berlin. Ersen was inspired by a newspaper article entitled "They Have Never Seen the Sea", about a group of people living in Istanbul who hadn't seen the Bosphorus as they lived in an isolated area on the outskirts of Istanbul. For this project, Ersen hires a bus and takes those people to a trip to Bosphorus, and one channel of the video shows them on the road, while another channel shows scenes from the places where they live. The video ends in a breaking point with the Bosphorus and lastly shows the reaction of the passengers when they see the sea.

It is important to draw attention to the general context of the video installation, as it grapples with the socio-economical position of these people living in the outskirts of Istanbul. The issues that Ersen aims to address with this work are the migration and urbanization of rural migrants living in this shantytown 16 and their urban adaptation. To bring to light the realities of this area in the outskirts of Istanbul, Ersen highlights the living conditions of rural migrants in this area. In general, the engagement process in this field-like setting, becoming a participant in the lives of these communities can be considered a link to participant observation method.

\section{'Raising Awareness' through Art}

By considering the Turkish case, I aimed to explore the historical and contemporary relations between the urban context and socially engaged art. In order to understand the role and the main intention of these collaborative and participatory practices, I exemplified the relationship of artists with the inhabitants of different city neighborhoods. Overall, the artists aim to influence social change through collaboration with the communities by bringing more visibility to their problems. In Turkey, these communities were all possible subjects of an ethnic conflict; and in general the works I exemplified are mostly engaged with communities living in marginalized areas with different ethnic identities. Art becomes a communication tool for these communities and a means of raising awareness to social issues.

I argue that the motivation to create these works was similar to the socially engaged practices that Bourriaud describes in terms of artists establishing social relations to "reintroduce the idea of plurality, for contemporary culture hailing from modernity, means inventing ways of being together, forms of interaction that go beyond the inevitability of the families, ghettos of technological user friendliness, and collective institutions an offer."17

The artists' main objectives coincide with this framework in terms of giving visibility to living in the marginalized areas and to minority communities. They generally position themselves as mediators for social change. The objectives of these artistic practices are essentially political and focus on "otherness". In regards to art having the potential for social research, each of these artists that I examined came up with a particular form 
of anthropology-related context and approach. By questioning these various tendencies, I described the Turkish case, aiming to shed a new light to the implications of doing a social research as an artist.

Through the confluences of urban studies, anthropology and art, I aimed to address the role of art practices in creating events for social interaction using participatory processes. Participatory approaches in contemporary art in Turkey through artistic activism coincide with the idea of artists creating 'micro-utopias', as Bourriaud calls them in Relational Aesthetics. Considering the social performativity of art in the production of social relations by creating events, I aimed to shed a new light on the potential of art for social change, as it is crucial to emphasize the implications of these artistic interventions on social relations.

\section{Bibliography}

BAYKAL, Emre - Contemporaneity in Turkish Art. In Unleashed: Contemporary Art from Turkey, by Hossein Amirsadeghi. London: TransGlobe, 2010, p. 40-47.

BISHOP, Claire - Artificial Hells: Participatory Art and the Politics of Spectatorship, 1st edn. London: Verso Books, 2012.

BISHOP, Claire - The Social Turn: Collaboration and Its Discontents. Artforum, February 2006, p. 178-83.

BOURRIAUD, Nicolas - Relational Aesthetics, trans. by Simon Pleasance and Fronza Woods, Book. Dijon - France: Les Presse Du Reel, 2002.

ÇAKIRLAR, Cüneyt - Aesthetics of Self-Scaling: Parallaxed Transregionalism and Kutluğ Ataman's Art Practice. Critical Arts, 27 (Kasım 1, 2013), 684-706. $<$ https://doi.org/10.1080/02560046.2013.867591>

INGOLD, Tim - Anthropology Contra Ethnography. HAU: Journal of Ethnographic Theory, 2017, p. 21-26.

KORTUN, Vasif; KOSOVA, Erden - Ofsayt, Ama Gol! (SALT/Garanti Kültür AȘ, 2014).

"Küba" Exhibition Opening Invitation' (TANAS Gallery, Berlin, 2008), SALT Research Turkish Artist Folders.

KWON, Miwon - One Place after Another: Notes on Site Specificity. October, 80 (1997), p. 85$110<$ https://doi.org/10.2307/778809>

MARCUS, George E. - Contemporary Fieldwork Aesthetics in Art and Anthropology: Experiments in Collaboration and Intervention. Visual Anthropology, 23, p. 263-77.

ODA PROJESI - Oda Projesi: Proje Amacı ve Aktivitelerini - Oda Projesi: Project Aim and Activities', 2001, Salt Research.

ÖZATALAY, Cem; ÖRNEK, Senem - From Modern to Contemporary Art: Transformations of Art Market in Istanbul. In Recent Developments in Sociology and Social Work., Proceedings of the XII. European Conference on Social and Behavioral Sciences (University of Catania, 2017), p. 369-79.

TAN, Pelin - Possibilities of Counter-Culture: Dissemination of Localities. In Tactics of Invisibility: Contemporary Artistic Positions from Turkey; [Nevin Aladağ, Kutluğ Ataman, Cevdet Erek...; Exhibition Catalogue of 'Tactics of Invisibility', Organized by ThyssenBornemisza Art Contemporary, Vienna and Vehbi Koç Foundation, Istanbul. ThyssenBornemisza Art Contemporary, Vienna April 16 to August 15, 2010, Tanas, Berlin 
September - December 2010, Arter, Istanbul, January - April 2011] (Köln: Walther König, 2010)

YARDIMCI, Sibel - Kuresellesen Istanbul'da Bienal, Sanat-Hayat, 8 (Istanbul: Iletisim Yayinlari, 2014), Istanbul.

\section{Biographical note}

Starting from her undergraduate education in Istanbul University, Anthropology Department, she has been interested in the theoretical and methodological aspects of anthropology. After her graduation, she got her MA Degree on Art Theory. She started her doctoral study in Istanbul Technical University, Department of Art History, and she obtained a PhD in Technische Universität Berlin in Art History department. Her research interests include the relation between art and anthropology, relational aesthetics and visual anthropology. Parallel to her research interests, she has organized workshops on "Art and Anthropology" in Akbank Sanat (Istanbul) and in Yıldız Technical University (Istanbul) in 2016. She has gained teaching experience as lecturer in Istanbul Aydın University, Marmara University and Technische Universität Berlin.

1 This article has been written based on author's unpublished doctoral thesis.

2 Sibel Yardimci, Kuresellesen Istanbul'da Bienal, Sanat-Hayat, 8 (Istanbul: Iletisim Yayinlari, 2014), p. 45, Istanbul.

${ }^{3}$ Cem Özatalay and Senem Örnek, 'From Modern to Contemporary Art: Transformations of Art Market in Istanbul', in Recent Developments in Sociology and Social Work., Proceedings of the XII. European Conference on Social and Behavioral Sciences (University of Catania, 2017), pp. 369-79. (p. 360).

${ }^{4}$ Diyarbakir Art Center and Sinopale would be an example for these attempts.

${ }^{5}$ Miwon Kwon, 'One Place after Another: Notes on Site Specificity', October, 80 (1997), 85-110 (p. 91).

${ }^{6}$ Claire Bishop, Artificial Hells: Participatory Art and the Politics of Spectatorship, 1st edn (London: Verso Books, 2012), p. 3, London.

7 Pelin Tan, 'Possibilities of Counter-Culture: Dissemination of Localities', in Tactics of invisibility: contemporary artistic positions from Turkey; [Nevin Aladağ, Kutluğ Ataman, Cevdet Erek...; Exhibition Catalogue of 'Tactics of Invisibility', organized by Thyssen-Bornemisza Art Contemporary, Vienna and Vehbi Koç Foundation, Istanbul. Thyssen-Bornemisza Art Contemporary, Vienna April 16 to August 15, 2010, Tanas, Berlin September-December 2010, Arter, Istanbul, January - April 2011] (Köln: Walther König, 2010), p. 146.

${ }^{8}$ Vasif Kortun and Erden Kosova, Ofsayt, Ama Gol! (SALT/Garanti Kültür AȘ, 2014), p. 34.

${ }^{9}$ George E. Marcus, 'Contemporary Fieldwork Aesthetics in Art and Anthropology: Experiments in Collaboration and Intervention', Visual Anthropology, 23.4, 263-77.

10 Tim Ingold, 'Anthropology Contra Ethnography', HAU: Journal of Ethnographic Theory, 2017, 21-26 (p. 24).

${ }^{11}$ Oda Project is an artist collective from Istanbul. The three artists, Özge Acikkol, Gunes Savas and Secil Yersel that formed Oda Projesi, turned their collaboration into a project. In a flat that they rented in Galata neighborhood, in Beyoglu-Istanbul they organized projects engaged with the society. Moreover, they conducted the project, Cultural Agencies in 2009, again with an aim 
of engagement with a marginalized community living in the outskirts of Istanbul. They created a platform for recording and sharing the neighborhood's collective memory with a series of interviews and generated practices to collect materials as an evidence of Gülsuyu's urbanization process.

${ }^{12}$ Derya Özkan, 'From the Black Atlantic to Cool Istanbul: Why Does Coolness Matter?', in Cool Istanbul: Urban Enclosures and Resistances, Urban Studies (Berlin De Gruyter, 2014), pp. 1333 (p. 18).

${ }^{13}$ Claire Bishop, 'The Social Turn: Collaboration and Its Discontents', Artforum, February 2006, 178-83 (p. 180).

14 “'Küba" Exhibition Opening Invitation' (TANAS Gallery, Berlin, 2008), SALT Research Turkish Artist Folders.

15 Cüneyt Çakirlar, 'Aesthetics of Self-Scaling: Parallaxed Transregionalism and Kutluğ Ataman's Art Practice', Critical Arts, 27.6 (November 1, 2013), 684-706 (p. 694).

${ }^{16}$ It is also possible translate shantytown as 'Gecekondu' area, as it is called in Turkish.

17 Nicolas Bourriaud, Relational Aesthetics, trans. by Simon Pleasance and Fronza Woods, Book (Dijon - France: Les Presse Du Reel, 2002), p. 60. 